\title{
Hypoglycaemia following removal of phaeochromocytoma: case report and review of the literature
}

\author{
STEPHEN CHAMBERS \\ M.R.A.C.P. \\ RICHARD A. DONALD \\ F.R.A.C.P.
}

\author{
ERIC A. ESPINER \\ F.R.A.C.P.
}

M. GARY NICHOLLS

F.R.A.C.P.

Endocrinology Department, The Princess Margaret Hospital, Christchurch, New Zealand

\begin{abstract}
Summary
Hypoglycaemia may complicate removal of a phaeochromocytoma, but its pathogenesis is not well understood. The sixth such case in the world literature is reported together with details of glucose tolerance testing and hormone levels before and after extirpation of an adrenal phaeochromocytoma. The mechanism of hypoglycaemia probably relates to a sudden decrease in circulating catecholamines which allows a rebound increase in insulin release and in peripheral glucose uptake. It is suggested that blood sugar levels should be monitored routinely after surgery for phaeochromocytoma.
\end{abstract}

\section{Introduction}

There have been only 5 reported cases of hypoglycaemia following removal of a phaeochromocytoma, and this complication is not mentioned in the comprehensive textbook by Manger and Gifford (1977). In this report we review the literature and describe a sixth case along with details of glucose, insulin, C-peptide, glucagon and catecholamine levels before and after resection of an adrenal phaeochromocytoma.

\section{Case report}

A 59-year-old forestry worker presented to this hospital because of poor control of diabetes mellitus. Diabetes had been diagnosed 6 months before when treatment was initiated with an oral hypoglycaemic agent. He subsequently suffered attacks of hunger, sweating and weakness which were attributed to hypoglycaemia although blood glucose levels were always normal or elevated. Questioning revealed a 3

Reprint requests to Dr Nicholls. year history of exertional headache and 2 years of intermittent hypertension. For 6 months he had noted increasing constipation and a $12-\mathrm{kg}$ weightloss.

On examination positive findings were a fine tremor, cool moist skin, blood pressure 198/98 $\mathrm{mmHg}$ supine, 194/112 $\mathrm{mmHg}$ standing, arteriovenous nipping in the fundi, and a third heart sound gallop rhythm.

Biochemical testing confirmed the diagnosis of phaeochromocytoma (Table 1). Plasma levels of noradrenaline, adrenaline and dopamine (Peuler and Johnston, 1977) were elevated as was the urinary excretion of catecholamines, vanillyl-mandelic acid (VMA) and total metanephrines. Treatment was initiated with labetalol, increasing from $400 \mathrm{mg}$ to $900 \mathrm{mg}$ daily which normalized blood pressure. A computed tomographic (CT) scan showed a $5 \mathrm{~cm}$ diameter mass above the left kidney. The premedication for anaesthesia was pethidine, promethazine, and phenoperidine. The patient was given an epidural anaesthetic at the level of T-8. General anaesthesia was induced with thiopentone and diallonortoxiferine and maintained with nitrous oxide. At operation a tumour $(6 \times 5 \times 4 \mathrm{~cm})$ arising from the left adrenal was found and removed along with the adrenal gland. Before removal of the tumour, arterial pressure was controlled by intermittent infusions of labetalol and nitroprusside. During the operation the patient received a total of $1500 \mathrm{ml}$ of stable plasma protein solution (SPPS), $350 \mathrm{ml}$ of $5 \%$ dextrose and $600 \mathrm{ml}$ of $4.3 \%$ dextrose and $0 \cdot 18 \%$ saline mixture. He returned to the recovery room with infusions of SPPS and $5 \%$ dextrose, and consciousness was regained some 15 min later. The dextrose infusion was stopped and the patient was given two units of whole blood. Approximately $2 \frac{1}{2} \mathrm{hr}$ after completion of surgery he became sweaty, unrousable and developed a tachycardia. A blood sample drawn urgently showed 
TABLE 1. Catecholamine and metabolite levels before and after removal of a phaeochromocytoma*

\begin{tabular}{lccc}
\hline Plasma & Noradrenaline & Adrenaline & Dopamine \\
\hline \multirow{3}{*}{ Pre-surgery } & $(150-800 \mathrm{pg} / \mathrm{ml})$ & $(15-120 \mathrm{pg} / \mathrm{ml})$ & $(20-150 \mathrm{pg} / \mathrm{ml})$ \\
Post-surgery & 2287 & 2026 & 803 \\
\hline Urine & 792 & 74 & - \\
\hline & Catecholamines & VMA ratio & Total metanephrines \\
Pre-surgery & $(<0.6 \mu \mathrm{mol} / 24 \mathrm{hr})$ & $(1.58-2.25)$ & $(<1.0 \mathrm{mg} / 24 \mathrm{hr})$ \\
Post-surgery & 7.1 & 1.05 & 3.6 \\
\hline
\end{tabular}

*Normal values are shown in parentheses.

hypoglycaemia (plasma glucose $1.9 \mathrm{mmol} /$ litre). His clinical state improved dramatically after the administration of $50 \mathrm{~g}$ glucose intravenously. He was maintained on an infusion of $4.3 \%$ dextrose and $0.18 \%$ saline at $60 \mathrm{ml} / \mathrm{hr}$ and had no further episodes of hypoglycaemia. The plasma glucose remained above $3.5 \mathrm{mmol} /$ litre.

Arterial pressure was normal after surgery and catecholamines and metabolite levels fell to normal levels (Table 1). The tumour showed typical features of a phaeochromocytoma on histological examination.

\section{Additional studies}

A $25 \mathrm{~g}$ intravenous glucose tolerance test was performed before surgery ( 4 days after commencing labetalol treatment) and again 14 days post-surgery off all medications. Along with glucose, blood samples were drawn for insulin (Scott et al., 1980), C-peptide (Scott et al., 1980) and glucagon estimations (Aquilar-Parada, Eisentraut and Unger, 1969). Glucagon was measured using a highly specific antiserum (M107). As shown in Fig. 1, fasting plasma glucose was elevated $(9.6 \mathrm{mmol} /$ litre $)$ presurgery and glucose disposal was markedly impaired (disposal constant, $\mathrm{Kg}, 0 \cdot 47$, normal >1.2). Plasma insulin and C-peptide levels were inappropriately low and showed no response to hyperglycaemia. After surgery, the fasting glucose level and the $\mathrm{Kg}$ values returned to normal and there was a dramatic increase in the response of both insulin and C-peptide to glucose loading (Fig. 1). Fasting plasma glucagon was raised before surgery and showed little response to intravenous glucose. In contrast, the fasting value was normal post-surgery and a normal decrement occurred in response to hyperglycaemia.

\section{Discussion}

Hypoglycaemia following removal of a phaeochromocytoma has been reported in 5 previous cases, details of which are listed in Table 2. Apart from the present case, none was clearly diabetic before sur- $\overline{0}$ gery. Hypoglycaemia was diagnosed within $2 \frac{1}{2} \mathrm{hr}$ of 3 completion of surgery in all patients despite the if concurrent administration of intravenous glucose solutions in at least two instances (patients 1 and $2, \infty$ Table 2). In only one instance (Patient 2) was insulin or measured at the time of hypoglycaemia and in this $\mathcal{\omega}$ case an inappropriately high level of plasma insulin was found. All patients responded well to concen- trated glucose solutions and no recurrence of hypo- $?$ glycaemia was documented.

Why transient hypoglycaemia should occur in $\stackrel{\frac{c}{\hookrightarrow}}{\oplus}$ some patients remains unclear but the sudden re $\overrightarrow{0}$ moval of the inhibitory effect of catecholamines 메 insulin secretion is likely to play a major part. Studies involving short term infusions of adrenaline normal man have shown rebound hyperinsulinism, inappropriate in relation to the prevailing plasma

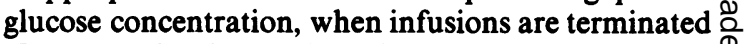

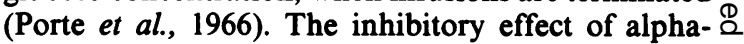
adrenergic stimulation on insulin secretion can also $\overrightarrow{\hat{O}}$ be rapidly reversed by alpha-adrenergic blocking $\exists$ drugs (Turnbull et al., 1980). In our patient the dramatic improvement in the ability to release insulin during glucose loading after removal of the $\overline{0}$ phaeochromocytoma is consistent with these studies. Other possible contributions to hypoglycaemia in- $\frac{\sigma}{3}$ clude enhanced peripheral glucose uptake and/or diminished hepatic glucose output, independent of $O$ change in insulin secretion. Catecholamines have $₹$ been shown to inhibit glucose uptake (Ellis, 1959) 응 and it is possible that this effect is rapidly reversed $\square$ after the resection of the tumour. Depletion of liver glycogen by high levels of adrenaline and glucagon $N$ before and during surgery may also contribute to hypoglycaemia. Short-term adrenaline infusions $N$

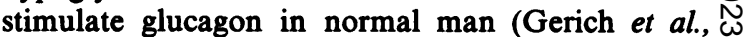
1974) and it is interesting to note that in- $\bar{\sigma}$ appropriately high levels of glucagon observedo presurgery were normalized in our patient after $\bar{\varnothing}$ surgery. Finally an effect of epidural anaesthesia on $\stackrel{\mathcal{P}}{+}$ the normal defence mechanism against hypoglycae- $\square$ mia cannot be dismissed. Neural afferent blockade $\stackrel{\vec{\Phi}}{\vec{D}}$ 
TABLE 2: Peri-operative data on six male patients with hypoglycaemia

\begin{tabular}{|c|c|c|c|c|c|c|}
\hline Author & No./Age & $\begin{array}{l}\text { Pre-surgery } \\
\text { blood glucose } \\
\text { (mmol/litre) }\end{array}$ & Drugs & Fluids & $\begin{array}{l}\text { Onset of } \\
\text { hypoglycaemia } \\
\text { post surgery }\end{array}$ & $\begin{array}{c}\text { Blood } \\
\text { glucose } \\
\text { (mmol/litre) }\end{array}$ \\
\hline $\begin{array}{l}\text { Martin, St Pierre } \\
\text { and Moliner } \\
(1979)\end{array}$ & $1 / 21$ & $\begin{array}{c}6.38 \\
\text { (Random) }\end{array}$ & $\begin{array}{l}\text { Pre-surgery } \\
\text { Phentolamine } \\
\text { Phenoxybenzamine } \\
\text { Propranolol } \\
\text { During surgery } \\
\text { Phentolamine }\end{array}$ & $\begin{array}{l}\text { Pre-surgery } \\
5 \% \text { Dextrose } \\
1 \text { litre over } \\
2 \mathrm{hr} 40 \mathrm{~min} \\
\text { Post-surgery } \\
125 \mathrm{ml} / \mathrm{hr}\end{array}$ & $40 \mathrm{~min}$ & $1 \cdot 88$ \\
\hline \multirow[t]{2}{*}{$\begin{array}{l}\text { Wilkins, Schmidt } \\
\text { and Doll } \\
\text { (1977) }\end{array}$} & $2 / 52$ & $\begin{array}{c}9 \cdot 4 \\
\text { (Random) } \\
7 \cdot 2 \\
\text { (Fasting) }\end{array}$ & $\begin{array}{l}\text { Pre-surgery } \\
\text { Phenoxybenzamine }\end{array}$ & $\begin{array}{l}\text { During surgery } \\
5 \% \text { dextrose } \\
250 \mathrm{ml} / \mathrm{hr} \\
\text { Post-surgery } \\
50 \mathrm{ml} / \mathrm{hr}\end{array}$ & $2 \mathrm{hr}$ & 0.99 \\
\hline & $3 / 12$ & $\begin{array}{c}4 \cdot 7 \\
\text { (Random) } \\
7 \cdot 1 \\
\text { (2 hr after food) }\end{array}$ & $\begin{array}{l}\text { Pre-surgery } \\
\text { Phenoxybenzamine }\end{array}$ & $\begin{array}{l}\text { During surgery } \\
5 \% \text { dextrose } \\
700 \mathrm{ml} \\
2 \frac{1}{2} \mathrm{hr}\end{array}$ & $30 \mathrm{~min}$ & 1.6 \\
\hline $\begin{array}{l}\text { Allen and } \\
\text { Imrie (1977) }\end{array}$ & $4 / 60$ & $\begin{array}{c}7.8 \\
\text { (Random) }\end{array}$ & $\begin{array}{l}\text { Pre-surgery } \\
\text { Phenoxybenzamine } \\
\text { Propranolol } \\
\text { During surgery } \\
\text { Propranolol }\end{array}$ & $\begin{array}{l}\text { During surgery } \\
5 \% \text { dextrose } \\
1.5 \text { litre }\end{array}$ & $2 \mathrm{hr}$ & 1.9 \\
\hline $\begin{array}{l}\text { Sagalowsky and } \\
\text { Donohue (1980) }\end{array}$ & $5 / 50$ & $\begin{array}{c}6 \cdot 1 \\
6 \cdot 4 \\
\text { (Random) }\end{array}$ & $\begin{array}{l}\text { Pre-surgery } \\
\text { Dibenzyline }\end{array}$ & $\begin{array}{l}\text { During surgery } \\
5 \% \text { dextrose } \\
\text { over } 6 \mathrm{hr}\end{array}$ & $\begin{array}{l}\text { Coma at end } \\
\text { of anaesthetic }\end{array}$ & 1.9 \\
\hline Chambers (1982) & $6 / 54$ & $\begin{array}{c}9 \cdot 5 \\
\text { (Fasting) }\end{array}$ & $\begin{array}{l}\text { Pre-surgery } \\
\text { Labetolol } \\
\text { During surgery } \\
\text { Labetolol }\end{array}$ & $\begin{array}{l}\text { During surgery } \\
5 \% \text { dextrose } \\
350 \mathrm{ml} \\
4.3 \% \text { dextrose } \\
600 \mathrm{ml}\end{array}$ & $2 \frac{1}{2} \mathrm{hr}$ & 1.9 \\
\hline
\end{tabular}

has been shown to attenuate the expected stressinduced rise in cortisol (Engquist et al., 1977) growth hormone (Brandt et al., 1976) and catecholamines (Halter and Pflug, 1980)-all of which are concerned with the counter regulatory effects of insulin-induced hypoglycaemia.

The effect of alpha and beta blocking drugs on glucose homeostasis is complex and difficult to assess in patients with phaeochromocytoma. All patients listed in Table 2 received alpha blocking agents which would be expected to increase the insulin response to glucose. Since beta blocking drugs would tend to inhibit insulin secretion, these drugs have been recommended in the peri-operative period to protect against hypoglycaemia (Sagalowsky and Donohue, 1980). Clearly, labetalol, a drug with mainly beta blocking activity, failed to protect against hypoglycaemia in the present case.

In conclusion, there are good physiological reasons why hypoglycaemia may occur after removal of phaeochromocytoma. The complication will not necessarily be prevented by standard glucose infusions. Signs of hypoglycaemia may be masked by beta- adrenergic blocking drugs and the diagnosis should be suspected in any patient who fails to gain consciousness or who loses consciousness in the early post-surgery period. In addition to glucose infusions we recommend that blood glucose levels should be measured as soon as the patient reaches the recovery room and at least once in the subsequent three hours in all patients after surgery for a phaeochromocytoma.

\section{Acknowledgments}

Grant support was from the Medical Research Council of New Zealand. We thank Dr Russell Scott for allowing us to study his patient, Mrs Carolyn Redekopp for glucagon assays and Mrs Natalie Purdue for typing the manuscript.

\section{References}

ALLEN, C.T.B. \& IMRIE, D. (1977) Hypoglycaemia as a complication of removal of a pheochromocytoma. Canadian Medical Association Journal, 116, 363.

Aquilar-Parada, E., Eisentraut, A.M. \& Unger, R.H. (1969) Pancreatic glucagon secretion in normal and diabetic subjects. American Journal of the Medical Sciences, 257, 415. 

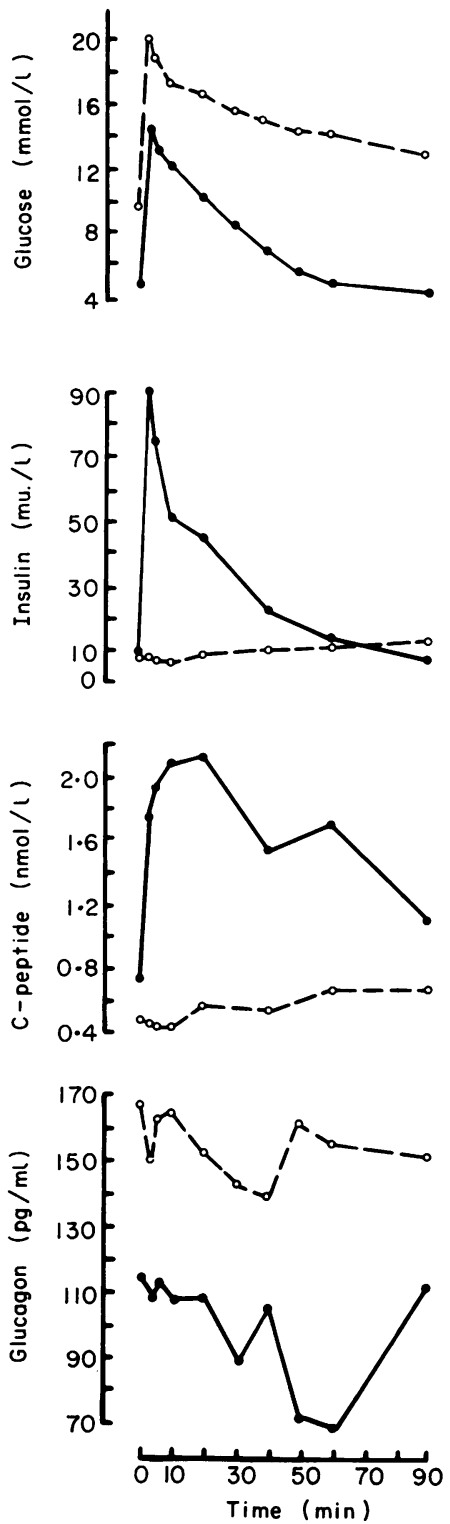

FIG. 1. Plasma levels of glucose, insulin, c-peptide and glucagon in response to a $25 \mathrm{~g}$ i.v. bolus of glucose before $(O)$ and after $(O)$ removal of a phaeochromocytoma. The $\mathrm{Kg}$ values were 0.47 before and 1.59 after surgery.
Brandt, M., Kehlet, H., Binder, C., Hagen, C. \& MCNeilly, A.S. (1976) Effect of epidural analgesia on the glycoregulatory endocrine response to surgery. Clinical Endocrinology, 5, 107.

ELLIS, S. (1959) Relation of biochemical effects of epinephrine to its vascular effects. Pharmacology Reviews, 11, 469.

Engquist, A., BrandT, M.R., Fernandes, A. \& Kehlet, H. (1977) The blocking effect of epidural analgesia on the adrenocortical and hyperglycaemic responses to surgery. Acta anaesthesiologica Scandinavica, 21, 330.

GERICH, J.E., SCHNEIDER, V., DiPPE, S.E., LANGlois, M., NoACCO, C., KARAM, J.H. \& ForShAM, P.H. (1974) Characterization of the glucagon response to hypoglycemia in man. Journal of Clinical Endocrinology and Metabolism, 38, 77.

Halter, J.B. \& Pflug, A.E. (1980) Relationship of impaired insulin secretion during surgical stress to anesthesia and catecholamine release. Journal of Clinical Endocrinology and Metabolism, 51, 1093.

MANGeR, W.M. \& GiffoRd, R.W. (1977) Pheochromocytoma. Springer, New York.

Martin, R., ST-Pierre, B. \& Moliner, O. (1979) Pheochromocytoma and postoperative hypoglycemia. Canadian Anaesthetist's Society Journal, 26, 260.

PEULER, J.D. \& JohnSton, G.A. (1977) Simultaneous single isotope radioenzymatic assay of plasma norepinephrine, epinephrine and dopamine. Life Science, 21, 625.

PORTE, JR D., Graber, A.L., KuZUYA, T. \& Williams, R.H. (1966) The effect of epinephrine on immunoreactive insulin levels in man. Journal of Clinical Investigation, 45, 228.

Sagalowsky, A. \& DonOHUE, J.P. (1980) Possible mechanism of hypoglycemia following removal of pheochromocytoma. Journal of Urology, 124, 422.

SCOTT, R.S., ESPINER, E.A., DoNALD, R.A. \& Ellis, M.J. (1980) Free insulin, c-peptide and glucagon profiles in insulin dependent $\mathscr{\varrho}$ diabetes mellitus. Australian and New Zealand Journal of Medig $\overrightarrow{\vec{O}}$ cine, 10, 146.

TURnBull, D.M., Johnston, D.G., AlberTi, K.G.M.M. \& Hali R. (1980) Hormonal and metabolic studies in a patient with pheochromocytoma. Journal of Clinical Endocrinology an Metabolism, 51, 930.

WILKINS, G.E., SCHMIDT, N. \& Doll, W.A. (1977) Hypoglycemia following excision of pheochromocytoma. Canadian Medical Association Journal, 116, 367. 